\title{
Novel Anticancer Curcumin Derivative with Conserved Functional Groups
}

\author{
Mohamed T. Abdel Aziz ${ }^{1 *}$, Mohamed F. El-Asmar², Ameen M. Rezq ${ }^{1}$, Hanan H. Fouad', Hanan H. Ahmed ${ }^{1}$, Amira A. Hassouna', Fatma M. Taha ${ }^{1}$
} and Hafez F. Hafez

\begin{abstract}
Background: Curcumin, a polyphenol from turmeric, has potent anticancer properties in human cancer cell lines. Nevertheless, its multitargeting clinical application in cancer and other diseases is hampered by its poor systemic bioavailability. A novel curcumin derivative "NCD" was developed through covalent modification of the curcumin "CUR" molecule on sites remote from its natural functional groups.

Methods: The NCD was tested for its anticancer effect against six human cancer cell lines in comparison to CUR and the standard anticancer drug Doxorubicin "DOX". In vivo structure-action relationship to the dose-dependent inducible plasma Glutathione S-transferase (GST) was studied. Plasma GST activity was estimated one and half and 24 hours after oral administration of each of CUR and the NCD.

Results: The NCD showed significantly lower Half-maximal inhibitory concentrations (IC50s) as compared to the DOX with each of HELA, the human cervical, MCF7, the human breast and HCT116, the human colonic cancer cell lines. Significant improvements in terms of lower IC50 as compared to CUR with all tested human cancer cell lines were also found. In vivo, the NCD showed significant elevations in inducible plasma GST in the $1.5 \mathrm{hr}$ and the $24 \mathrm{hr}$ duration studies as compared to CUR.

Conclusion: The IC50 anticancer effect of the NCD significantly was improved against six human cancer cell lines in comparison to CUR. The NCD retained an improved potency in terms of in vivo structure-action relationship to dose-dependent induction of plasma GST. With GST as biomarker for cancer, it should not be taken as parameter in studies and/or clinical trial involving both cancer and CUR as GST is dosedependently inducible by CUR and some of its derivatives.
\end{abstract}

\section{Introduction}

While cancer initiation and development implicates often hundreds of genes and/or signaling cascades, most conventional chemotherapeutic agents used today were designed to hit a single intracellular target, meanwhile, exerting a number of frequent severe adverse side effects, together with lack of safety. Hence, efforts are directed to the development of multi-targeting therapies especially from natural phytochemicals which are safe and inexpensive.

Fulfillment of such potentials was found with curcumin (diferuloylmethane), a natural polyphenol from the rhizomes of Curcuma longa. Either native or modified, it exhibits the ability to affect multiple intracellular targets [1,2] potentially useful for both prevention and treatment of multifactorial diseases such as cancer, by inhibiting specific molecular signaling pathways involved in carcinogenesis [3-5]. The reported activity of curcumin against leukemia, lymphoma, gastrointestinal, genitourinary, breast, ovarian, head and neck squamous cell carcinoma, lung, melanoma, neurological cancers, and sarcomas reflects its ability to affect multiple targets [1-6]. In vitro, curcumin has been reported to be antiproliferative in a number of cells lines $[4,5,7]$, with toxicity significantly higher in tumor cells compared to the normal cells [8]. Therefore, curcumin can be considered as an ideal lead compound for anticancer drug development with safety up to12 g/ day [9-11], but its very poor bioavailability in both plasma and tissues $[12,13]$ hampers the advancement of its clinical use.

To overcome such limitations, several approaches have been

Correspondence: talaatabdaziz@yahoo.co.uk

${ }^{1}$ Unit of Biochemistry and Molecular Biology, the Medical Biochemistry

Department, Faculty of Medicine, Cairo University, Egypt.

Full list of author information is available at the end of the article tested; including the covalent modification of the curcumin molecule. For example, multiple myeloma remains an incurable malignancy despite the recent approval of new molecular targeted agents; however, a newly synthesized curcumin analogue showed 7 to 12 fold more potent growth suppression of myeloma cells [14]. Nevertheless, such covalent modifications need to be tested in terms of in vivo structure-action relationships. In this respect, several types of cellular and body fluids components were recognized as biomarkers for curcumin action, whose efficacy appears to be related to dose dependent induction of glutathione-S-transferase (GST), inhibition of prostaglandin-E2 production and suppression of oxidative DNA adduct M1G formation [15]. Glutathione S-transferases (GSTs), are a family of phase II detoxification enzymes that catalyze the conjugation of glutathione with a number of hydrophobic compounds. On the other hand, it is highly expressed in tumors and plasma of cancer patients; and is considered a useful prognostic factor to determine the clinical outcome of chemotherapy [16].

In the present study, a novel curcumin derivative "NCD" was developed through covalent modification of the curcumin molecule on sites remote from its natural functional groups. The first aim of the present work was to evaluate the anticancer effect of the "NCD" against some human cancer cell lines with the assumption of improvements to its natural potencies in terms of significantly lower micro molar IC50, in comparison with natural curcumin "CUR" and the standard anticancer drug Doxorubicin "DOX".

Secondly, to determine whether the "NCD" still retains the essential potencies of natural curcumin, as applied to living cells/organism. Accordingly, a comparative in vivo study of the plasma levels of the dose-dependent inducible GST, as a biomarker of curcumin action was conducted. Based on such planning, it should be possible to shed 
Abdel Aziz et al. Journal of Cancer Therapeutics \& Research 2012,

http://www.hoajonline.com/journals/pdf/2049-7962-1-10.pdf

doi: $10.7243 / 2049-7962-1-10$

light on the firm conservation of the original biochemical, functions/ potencies of natural curcumin within the novel curcumin derivative.

\section{Materials and Methods}

A novel curcumin derivative "NCD" was developed through covalent modification of the curcumin molecule on sites remote from its natural functional groups. It was presented free of charge to the participating researchers as a personal non-profit scientific gift to help advancement of cooperation in national medical research. The novel derivative, (PCT/EG2008/000044, WO 2010/057503, Regional phase European Patent Application No. 08878223) was registered as international patent protected by the rights of "The Patent Cooperation Treaty" and is the personal property of its inventors, Rezq et al., 2008 [17].

Test compounds: Standard Doxorubicin hydrochloride "DOX" (Adriamycin, with mol. mass 579.98), natural curcumin "CUR" (with mean mol. mass 338.00) and the novel curcumin derivative "NCD", (with estimated mol. mass 636.00).

Human cell lines: Six different human cancer cell lines were used in this study together with the normal nonmalignant melanocytes cell line (HFB4). The human cancer cell lines included: the cervical cancer cell line (HELA), laryngeal carcinoma cell line (HEP2), breast cancer cell line (MCF7), hepatocellular cell line (HEPG2), colorectal cancer cell line (Caco2) and colonic cancer cell line (HCT116). All cell lines were purchased from the American Type Culture Collection (ATCC) Manassas, VA USA frozen in liquid nitrogen, then stored and maintained at the laboratories of the National Cancer Institute, Cairo, Egypt, by serial sub-culturing. Cell viability was determined by trypan blue exclusion method using the inverted microscope according to Stoddart, 2011[18].

Assay of anti cancer cytotoxic activity: The assay was carried out according to the SRB assay of Skehan et al., 1990 [19]. The sensitivity of the human cancer cell lines to increasing serial concentrations equivalent to $0,5,12.5,25$ and $50 \mu \mathrm{g} / \mathrm{ml}$ of each of the standard Doxorubicin hydrochloride "DOX" (Adriamycin), natural curcumin "CUR" and the novel curcumin derivative "NCD" were compared.

\section{Dose-dependent inducible plasma glutathione-S-transferase:} One and half and 24 hours' duration studies were conducted to determine the dose response characteristics of curcumin CUR and its novel derivative NCD on inducible plasma GST. The study was carried on 170 male white albino rats, of an average weight 150-200 gm from an inbred colony (Curl: HEL 1), at the Kasr Al-Aini experimental animals unit, Faculty of Medicine, Cairo University. Rats were bred and maintained in air-conditioned pathogen-free conditions, with 12:12 hr daylight/darkness cycles and allowed free access to chow and water. Ethical protocols for animal treatment were followed with approval from the Institutional Animal Care Committee. The rats were divided into 17 groups, each of 10 rats: a control group, 4 duplicated groups that received pure curcumin suspended in 1 $\mathrm{ml}$ of water orally at doses equivalent to $37,74,148$ and $296 \mu \mathrm{M} / \mathrm{kg}$ body weight respectively. In addition another 4 duplicated groups received the novel curcumin derivative dissolved in $1 \mathrm{ml}$ of water orally on the same equimolar bases. The control group received an equal oral volume of water. One and half hour and 24 hours after oral administration of the respective doses of each compound, venous blood samples were withdrawn from the tail veins of the proper corresponding group, to estimate plasma GST activity according to the method of Habig et al., 1974 [20].

Calculations and statistical analysis: Half-maximal inhibitory concentrations (IC50s) dose-response curves were constructed after conversion of the concentrations of the experimental test compounds with different molecular masses to micro molar equivalents for proper accurate comparisons. The (IC50s) were determined using the software package "OriginPro-8" of OriginLab Corporation USA. A nonlinear sigmoidal curve fit based on the "Boltzmann" model was applied using the equation: $y=A 2+(A 1-A 2) /(1+\exp ((x-x 0) /$ $\mathrm{dx})$ ), where $\mathrm{y}=\mathrm{IC} 50$. Standard and test compounds IC50 values in $\mu \mathrm{mol} / \mathrm{ml}$ were calculated from the appropriate linear segment of the correlation line for each of the tested normal and human cancer cell lines. Each curve was constructed from 6X6 increasing serial concentrations of the test compound.

Arithmetic means of IC50 each representing six points with intraassay S.D. of each tested compound were subjected to the Student $t$-test at $p<0.05$ to determine the significance of difference of mean IC50 values in $\mu \mathrm{mol} / \mathrm{ml}$ using the software package "Statistica- 8 " of Statsoft Inc. USA. The percentage of difference between the IC50 of the three test compounds was calculated to compare their relative potencies and/or improvements in terms of significantly lower micro molar IC50 if any.

The one and half hour and the extended, (24 hours) inducible plasma GST dose response curves for each of curcumin CUR and its novel derivative NCD were constructed using mean GST U/L \pm S.D as percentage change relative to the normal control levels. The student t-test was applied at $\mathrm{p}<0.05$ to test the significance of differences of mean plasma inducible GST levels allover the whole induction dose range of serial doubling equimolar concentrations of CUR and NCD. The non-linear distance weighted least square fit procedure was applied to construct correlation dose response lines of plasma inducible GST percentage of change to each of CUR and NCD.

\section{Results}

Following the mathematical and statistical analysis models applied in this study it was possible to reach solid inferences about the significance of difference of mean IC50 values in micro molar expression and percentage of difference between the IC50 of each of the three tested compounds relative potencies and/or improvement.

The results of the comparative in vivo plasma levels of inducible glutathione-S-transferase, for the 1.5 and the 24 hours' duration studies are presented as mean percent change relative to the normal control levels together with the statistical analysis of the significance of differences in dose response characteristics of CUR and its novel derivative NCD on inducible plasma GST with respect to time and to each other. 
Mean IC50 values: Table 1 and Figure 1, show the statistical analysis of the mean IC50 of the three tested compounds in $\mu \mathrm{mol} / \mathrm{ml} \pm$ intra-assay six point S.D. as tested against the one normal and six human cancer cell line cultures using the Student t-test at $\mathrm{p}$-values $<0.05$, while Table 2 and Figure 2 show the percentage difference analysis of the same results.

It is clear from Table 1 and Figure 1 that both CUR and NCD have high human anticancer survival inhibitory potentials in the micro molar range against several human cancer cell line cultures. As for DOX, the most sensitive was the HFB4 human normal nonmalignant melanocyte cell line with a mean IC50 of $5.23 \pm 0.24 \mu \mathrm{mol} / \mathrm{ml}$ and the least sensitive was the HCT116 human colonic cancer cell line with a mean IC50 of $7.46 \pm 0.95 \mu \mathrm{mol} / \mathrm{ml}$. Curcumin showed the same towards the HFB4 human normal nonmalignant melanocyte cell line with a mean IC50 of $7.64 \pm 0.08 \mu \mathrm{mol} / \mathrm{ml}$ and was least effective against the CACO2 human colorectal cancer cell line with a mean IC50 of $5.27 \pm 0.19 \mu \mathrm{mol} / \mathrm{ml}$. However, as for NCD, it showed improved lower mean IC50 dose response as compared to CUR, being most effective against the HCT116 human colonic cancer cell line with a mean IC50 of $5.34 \pm 0.43 \mu \mathrm{mol} / \mathrm{ml}$ and least effective against the CACO2 human colorectal cancer cell line with a mean IC50 of $6.13 \pm 0.50 \mu \mathrm{mol} / \mathrm{ml}$. An over all comparison showed that the micro molar IC50 of CUR is significantly higher than the standard DOX with all tested human cancer cell lines and that NCD has significantly lower mean IC50 dose response as compared to DOX in case of HELA, the human cervical cancer cell line, MCF7, the human breast cancer cell line and the HCT116 human colonic cancer cell line. However, NCD showed a statistically non-significant difference from DOX with both HEP2, the larynx human cancer cell line and HEPG2, the human hepatic cancer cell line, while it was less effective than DOX against the HFB4 human normal nonmalignant melanocyte cell line and CACO2 the human

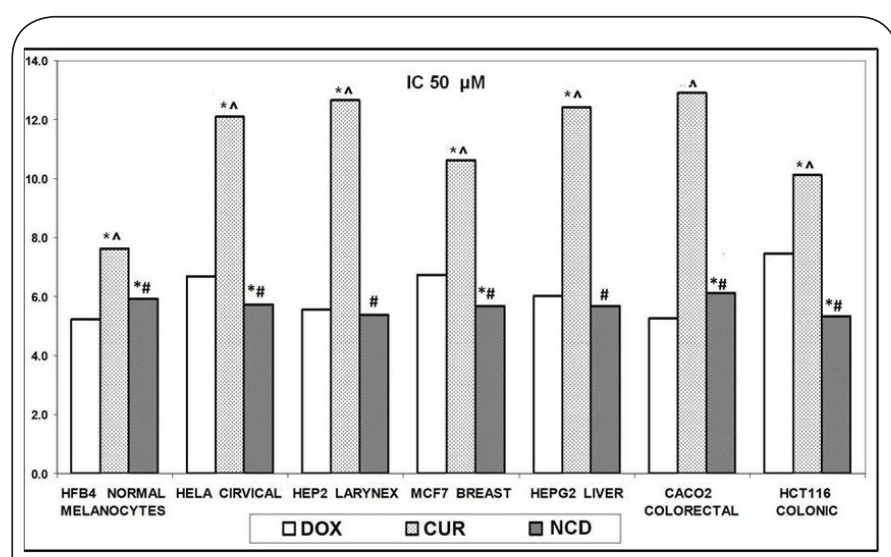

Figure 1. Relative micro molar IC50 of DOX, CUR and NCD against different human cancer cell lines

* = Statistically significantly different from DOX.

\# = Statistically significantly different from CUR.

$\wedge=$ Statistically significantly different from NCD. colorectal cancer cell line. Nevertheless, going with the research assumption, the NCD showed the "desirable" high improvement; with statistically significantly lower mean IC50 dose response as compared to CUR with all tested human cancer cell lines.

Mean IC50 percentage change: Table 2 and Figure 2 express the results in terms of percentage difference of IC50 of the three tested compounds against the one normal and six human cancer cell lines to compare the relative potencies and/or improvements in terms of significantly lower IC50 if any.

The micro molar IC50 of CUR is higher than the standard DOX with all tested human normal nonmalignant and cancer cell lines ranging from 108.7 to 245.0 percent for HELA, the human cervical cancer cell line and CACO2 the human colorectal cancer cell line respectively. The same applies for NCD against the standard DOX with statistically significantly lower micro molar IC50 ranging from 71.6 to 96.8 percent for HCT116 human colonic cancer cell line and HEP2, the larynx human cancer cell line respectively except with HFB4 normal nonmalignant melanocytes cell line and the human colorectal cancer CACO2 which showed higher percent values of 113.2 and $116.3 \%$ respectively.

On the other hand, and going with the research assumption, the NCD showed high improvement with statistically significantly lower micro molar IC50 than CUR with all tested human normal nonmalignant and cancer cell lines ranging from 42.5 to 77.5 percent for HEP2, the larynx human cancer cell line and HFB4 normal nonmalignant melanocytes cell line respectively.

Inducible GST: Table 3 and Figure 3 show the results of the comparative in vivo plasma levels of inducible glutathione-S-transferase, for the 1.5 and the 24 hours' duration studies as mean percent change

Table 1. Statistical analysis of the difference in IC50 of CUR and NCD as compared to DOX against different human cancer cell lines.

\begin{tabular}{|c|c|c|c|}
\hline CELL LINE TYPE & $\begin{array}{c}\text { DOX } \\
\text { IC50 } \mu \mathrm{mol} / \mathrm{ml} \\
\text { MEAN } \pm \text { S.D. }\end{array}$ & $\begin{array}{c}\text { CUR } \\
\text { IC50 } \mu \mathrm{mol} / \mathrm{ml} \\
\mathrm{MEAN} \pm \text { S.D. }\end{array}$ & $\begin{array}{c}\text { NCD } \\
\text { IC50 } \mu \mathrm{mol} / \mathrm{ml} \\
\mathrm{MEAN} \pm \text { S.D. }\end{array}$ \\
\hline $\begin{array}{l}\text { HFB4 } \\
\text { NORMAL NONMA- } \\
\text { LIGNANT } \\
\text { MELANOCYTES }\end{array}$ & $5.23 \pm 0.24$ & $\begin{array}{c}7.64 \pm 0.08 \\
\text { t-test } \\
\text { vs. DOX } p<0.001 \uparrow\end{array}$ & $\begin{array}{c}5.92 \pm 0.61 \\
\text { t-test } \\
\text { vs. DOX p<0.05个 } \\
\text { vs. CUR p }<0.001 \downarrow\end{array}$ \\
\hline $\begin{array}{l}\text { HELA } \\
\text { CERVICAL CANCER }\end{array}$ & $6.69 \pm 0.49$ & $\begin{array}{c}12.09 \pm 1.16 \\
\text { t-test } \\
\text { vs. DOX } \mathrm{p}<0.001 \uparrow\end{array}$ & $\begin{array}{c}5.73 \pm 0.54 \\
\text { t-test } \\
\text { vs. DOX p<0.05 } \\
\text { vs. CUR p }<0.001 \downarrow\end{array}$ \\
\hline $\begin{array}{l}\text { HEP2 } \\
\text { LARYNEX CANCER }\end{array}$ & $5.56 \pm 0.43$ & $\begin{array}{c}12.67 \pm 1.09 \\
\text { t-test } \\
\text { vs. } D O X p<0.001 \uparrow\end{array}$ & $\begin{array}{c}5.38 \pm 0.39 \\
\text { t-test } \\
\text { vs. DOX }=\text { N.S. } \downarrow \\
\text { vs. CUR } \mathrm{p}<0.001 \downarrow\end{array}$ \\
\hline $\begin{array}{l}\text { MCF7 } \\
\text { BREAST CANCER }\end{array}$ & $6.75 \pm 0.87$ & $\begin{array}{c}10.63 \pm 0.82 \\
\text { t-test } \\
\text { vs. DOX } \mathrm{p}<0.001 \uparrow\end{array}$ & $\begin{array}{c}5.67 \pm 0.59 \\
\text { t-test } \\
\text { vs. DOX } \mathrm{p}<0.05 \downarrow \\
\text { vs. CUR } \mathrm{p}<0.001 \downarrow\end{array}$ \\
\hline $\begin{array}{l}\text { HEPG2 } \\
\text { HEPATIC CANCER }\end{array}$ & $6.03 \pm 0.58$ & $\begin{array}{c}12.43 \pm 0.78 \\
\text { t-test } \\
\text { vs. DOX } \mathrm{p}<0.001 \uparrow\end{array}$ & $\begin{array}{c}5.68 \pm 0.61 \\
\text { t-test } \\
\text { vs. DOX }=\mathrm{N} . S . \downarrow \\
\text { vs. CUR } \mathrm{p}<0.001 \downarrow\end{array}$ \\
\hline $\begin{array}{l}\text { CACO2 COLORECTAL } \\
\text { CANCER HCT116 } \\
\text { COLONIC CANCER }\end{array}$ & $5.27 \pm 0.19$ & $\begin{array}{c}12.91 \pm 0.47 \\
\text {-test } \\
\text { vs. } D O X \mathrm{p}<0.001 \uparrow\end{array}$ & $\begin{array}{c}6.13 \pm 0.50 \\
\text {-test } \\
\text { vs. DOX } p<0.005 \uparrow \\
\text { vs. CUR } \mathrm{p}<0.001 \downarrow\end{array}$ \\
\hline $\begin{array}{l}\text { HCT116 } \\
\text { COLONIC CANCER }\end{array}$ & $7.46 \pm 0.95$ & $\begin{array}{c}10.12 \pm 0.72 \\
\text { t-test } \\
\text { vs. DOX } p<0.001 \uparrow\end{array}$ & $\begin{array}{c}5.34 \pm 0.43 \\
\text { t-test } \\
\text { vs. DOX } \mathrm{p}<0.001 \downarrow \\
\text { vs. CUR } \mathrm{p}<0.001 \downarrow\end{array}$ \\
\hline
\end{tabular}


Abdel Aziz et al. Journal of Cancer Therapeutics \& Research 2012,

http://www.hoajonline.com/journals/pdf/2049-7962-1-10.pdf

doi: $10.7243 / 2049-7962-1-10$

Table 2. Percentage difference in IC50 of CUR and NCD as compared to DOX against different human cancer cell lines.

\begin{tabular}{|c|c|c|c|c|c|c|c|c|}
\hline \multirow{4}{*}{$\begin{array}{l}\text { CELL LINE TYPE } \\
\text { HFB4 } \\
\text { NORMAL NONMA- } \\
\text { LIGNANT } \\
\text { MELANOCYTES }\end{array}$} & \multirow{4}{*}{$\begin{array}{c}\text { DOX } \\
\text { IC50 } \mu \mathrm{mol} / \\
\text { ml MEAN } \pm \\
\text { S.D. } \\
\\
5.23 \pm 0.24\end{array}$} & \multirow{4}{*}{$\begin{array}{c}\text { CUR } \\
\text { IC50 } \mu \mathrm{mol} / \mathrm{ml} \\
\text { MEAN } \pm \text { S.D. } \\
7.64 \pm 0.08 \\
\text { percent } \\
\% \text { of DOX }=146.1 \uparrow\end{array}$} & \multirow{4}{*}{$\begin{array}{c}\text { NCD } \\
\text { IC50 } \mu \mathrm{mol} / \mathrm{ml} \\
\text { MEAN } \pm \text { S.D. } \\
5.92 \pm 0.61 \\
\text { percent } \\
\text { \% of DOX }=113.2 \uparrow \\
\text { \% of CUR }=77.5 \downarrow\end{array}$} & \multicolumn{5}{|c|}{$\begin{array}{l}\text { Table 3. Plasma inducible GST (U/L), Mean } \pm \text { S.D., percent change from control } \\
\text { and statistical analysis of differences with respect to time and CUR vs. NCD. }\end{array}$} \\
\hline & & & & \multicolumn{5}{|c|}{ CONTROL $=164.23 \pm 8.56 \mathrm{U} / \mathrm{L}$} \\
\hline & & & & CUR / TIME & CUR $37 \mu \mathrm{M} / \mathbf{k g}$ & CUR $74 \mu \mathrm{M} / \mathrm{kg}$ & CUR $148 \mu \mathrm{M} / \mathrm{kg}$ & CUR $296 \mu \mathrm{M} / \mathrm{kg}$ \\
\hline & & & & $11 / 2 \mathrm{hr}$ & $\begin{array}{c}162.71 \pm 8.12 \\
\text { Percent }-0.59 \downarrow\end{array}$ & $\begin{array}{c}161.26 \pm 8.25 \\
\text { Percent }-1.61 \downarrow\end{array}$ & $\begin{array}{l}207.27 \pm 13.50 \\
\text { Percent } 26.63 \uparrow\end{array}$ & $\begin{array}{l}213.49 \pm 11.16 \\
\text { Percent } 30.41 \uparrow\end{array}$ \\
\hline \multirow{2}{*}{$\begin{array}{l}\text { HELA } \\
\text { CERVICAL CANCER }\end{array}$} & \multirow[t]{2}{*}{$6.69 \pm 0.49$} & \multirow{2}{*}{$\begin{array}{c}12.09 \pm 1.16 \\
\text { percent } \\
\% \text { of DOX }=108.7 \uparrow\end{array}$} & \multirow{2}{*}{$\begin{array}{c}5.73 \pm 0.54 \\
\text { percent } \\
\% \text { of DOX }=85.7 \downarrow \\
\% \text { of CUR }=47.4 \downarrow\end{array}$} & $24 \mathrm{hr}$ & $\begin{array}{r}164.87 \pm 5.46 \\
\text { Percent } 0.59 \uparrow\end{array}$ & $\begin{array}{c}162.10 \pm 6.34 \\
\text { Percent }-1.04 \downarrow \\
\end{array}$ & $\begin{array}{l}172.53 \pm 10.16 \\
\text { Percent } 5.28 \uparrow\end{array}$ & $\begin{array}{c}181.97 \pm 9.98 \\
\text { Percent } 11.05 \uparrow\end{array}$ \\
\hline & & & & t-test vs. & N.S. $\uparrow$ & N.S. $\downarrow$ & $\mathrm{p}<0.001 \downarrow$ & $\mathrm{p}<0.001 \downarrow$ \\
\hline \multirow{2}{*}{$\begin{array}{l}\text { HEP2 } \\
\text { LARYNEX CANCER }\end{array}$} & \multirow{2}{*}{$5.56 \pm 0.43$} & \multirow{2}{*}{$\begin{array}{c}12.67 \pm 1.09 \\
\text { percent } \\
\% \text { of DOX }=227.9 \uparrow\end{array}$} & \multirow{2}{*}{$\begin{array}{c}5.38 \pm 0.39 \\
\text { percent } \\
\% \text { of DOX }=96.8 \downarrow \\
\% \text { of } \mathrm{CUR}=42.5 \downarrow\end{array}$} & $\frac{11 / 2 \mathrm{hr}}{\mathrm{NCD} / \mathrm{TIME}}$ & $\mathrm{NCD} 37 \mu \mathrm{M} / \mathrm{kg}$ & $\mathrm{NCD} 74 \mu \mathrm{M} / \mathrm{kg}$ & $\mathrm{NCD} 148 \mu \mathrm{M} / \mathrm{kg}$ & NCD $296 \mu \mathrm{M} / \mathrm{kg}$ \\
\hline & & & & \multirow{2}{*}{$11 / 2 \mathrm{hr}$} & \multirow{2}{*}{$\begin{array}{c}155.24 \pm 9.61 \\
\text { Percent }-5.36 \downarrow\end{array}$} & \multirow{2}{*}{$\begin{array}{l}158.14 \pm 10.63 \\
\text { Percent }-3.41 \downarrow\end{array}$} & \multirow{2}{*}{$\begin{array}{c}210.61 \pm 9.99 \\
\text { Percent } 28.56 \uparrow\end{array}$} & \multirow{2}{*}{$\begin{array}{r}249.22 \pm 19.96 \\
\text { Percent } 51.70 \uparrow\end{array}$} \\
\hline \multirow[b]{2}{*}{$\begin{array}{l}\text { MCF7 } \\
\text { BREAST CANCER }\end{array}$} & \multirow[b]{2}{*}{$6.75 \pm 0.87$} & \multirow{2}{*}{$\begin{array}{c}10.63 \pm 0.82 \\
\text { percent } \\
\% \text { of DOX }=157.5 \uparrow\end{array}$} & \multirow{2}{*}{$\begin{array}{c}5.67 \pm 0.59 \\
\text { percent } \\
\% \text { of DOX }=86.0 \downarrow \\
\% \text { of CUR }=52.7 \downarrow\end{array}$} & & & & & \\
\hline & & & & $\begin{array}{l}\text { t-test vs. } \\
\text { CUR }\end{array}$ & $\mathrm{p}<0.05 \downarrow$ & N.S. $\downarrow$ & N.S. $\uparrow$ & $\mathrm{p}<0.001 \uparrow$ \\
\hline \multirow{2}{*}{$\begin{array}{l}\text { HEPG2 } \\
\text { HEPATIC CANCER }\end{array}$} & \multirow{2}{*}{$6.03 \pm 0.58$} & \multirow{2}{*}{$\begin{array}{c}12.43 \pm 0.78 \\
\text { percent } \\
\% \text { of DOX }=206.1 \uparrow\end{array}$} & \multirow{2}{*}{$\begin{array}{c}5.68 \pm 0.61 \\
\text { percent } \\
\% \text { of DOX }=94.2 \downarrow \\
\% \text { of CUR }=45.7 \downarrow\end{array}$} & $24 \mathrm{hr}$ & $\begin{array}{c}153.96 \pm 6.50 \\
\text { Percent }-6.08 \downarrow\end{array}$ & $\begin{array}{l}160.88 \pm 13.47 \\
\text { Percent }-1.64 \downarrow\end{array}$ & $\begin{array}{l}177.33 \pm 10.73 \\
\text { Percent } 8.11 \uparrow\end{array}$ & $\begin{array}{l}205.73 \pm 20.59 \\
\text { Percent } 25.36 \uparrow\end{array}$ \\
\hline & & & & $\begin{array}{l}\text { t-test vs. } \\
11 / 2 \mathrm{hr}\end{array}$ & N.S. $\downarrow$ & N.S. $\downarrow$ & $\mathrm{p}<0.001 \downarrow$ & $\mathrm{p}<0.001 \downarrow$ \\
\hline \multirow{2}{*}{$\begin{array}{l}\text { CACO2 } \\
\text { COLORECTAL } \\
\text { CANCER }\end{array}$} & \multirow[t]{2}{*}{$5.27 \pm 0.19$} & \multirow{2}{*}{$\begin{array}{c}12.91 \pm 0.47 \\
\text { percent } \\
\% \text { of DOX }=245.0 \uparrow\end{array}$} & \multirow{2}{*}{$\begin{array}{c}6.13 \pm 0.50 \\
\text { percent } \\
\% \text { of DOX }=116.3 \uparrow \\
\% \text { of CUR }=47.5 \downarrow\end{array}$} & $\begin{array}{l}\text { t-test vs. } \\
\text { CUR }\end{array}$ & $\mathrm{p}<0.001 \downarrow$ & N.S. $\downarrow$ & N.S. $\uparrow$ & $\mathrm{p}<0.005 \uparrow$ \\
\hline & & & & \multirow{2}{*}{\multicolumn{2}{|c|}{ N.S. = Statistically Non-S }} & gnificant differe & ce. & \\
\hline $\begin{array}{l}\text { HCT116 } \\
\text { COLONIC CANCER }\end{array}$ & $7.46 \pm 0.95$ & $\begin{array}{c}10.12 \pm 0.72 \\
\text { percent } \\
\% \text { of DOX }=135.7 \uparrow\end{array}$ & $\begin{array}{c}5.34 \pm 0.43 \\
\text { percent } \\
\% \text { of DOX }=71.6 \downarrow \\
\% \text { of CUR }=52.8 \downarrow\end{array}$ & & & & & \\
\hline
\end{tabular}

Table 4. Non-linear distance weighted least square fit of dose response curves of mean plasma inducible GST percentage of change to each of CUR and NCD.

\begin{tabular}{lccc}
\hline STUDY & Distance weighted L. S. F. & Coefficient & Significance \\
\hline CUR 1.5 hr & $\mathrm{y}=-4.60+0.13^{\star} \mathrm{x}$ & $\mathrm{r}=0.75$ & $\mathrm{p}<0.001$ \\
CUR 24 hr & $\mathrm{y}=-2.35+0.05^{\star} \mathrm{x}$ & $\mathrm{r}=0.55$ & $\mathrm{p}<0.001$ \\
NCD 1.5 hr & $\mathrm{y}=-14.42+0.23{ }^{\star} \mathrm{x}$ & $\mathrm{r}=0.92$ & $\mathrm{p}<0.001$ \\
NCD 24 hr & $\mathrm{y}=-10.44+0.12{ }^{*} \mathrm{x}$ & $\mathrm{r}=0.81$ & $\mathrm{p}<0.001$ \\
\hline
\end{tabular}

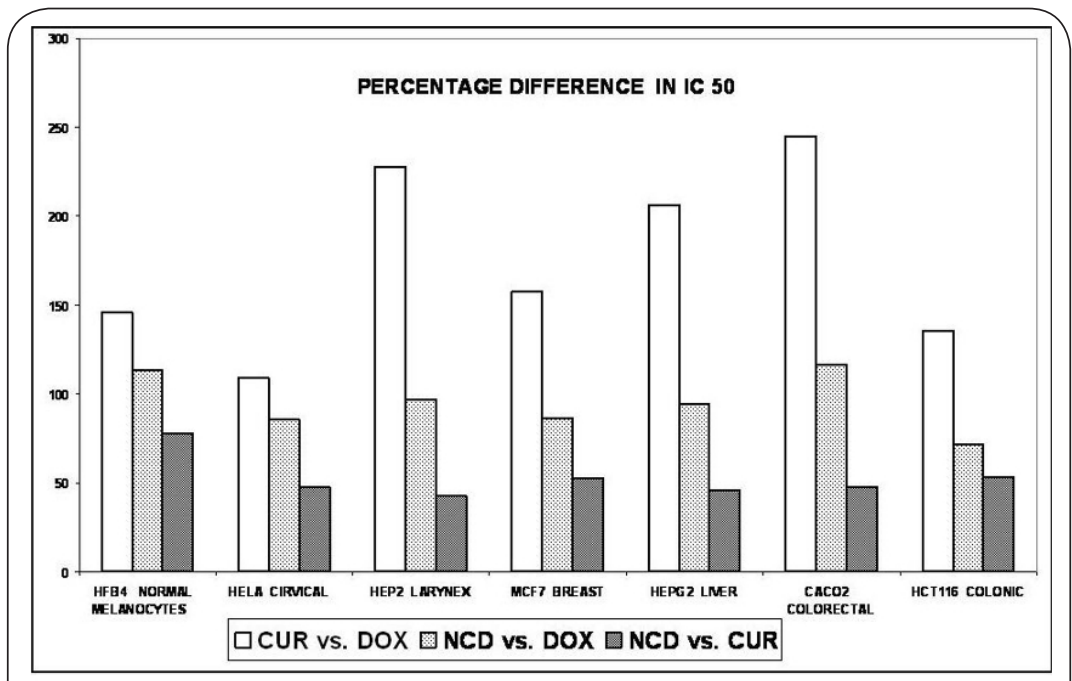

Figure 2. Percentage difference IC50 of DOX, CUR and NCD against different human cancer cell lines. 


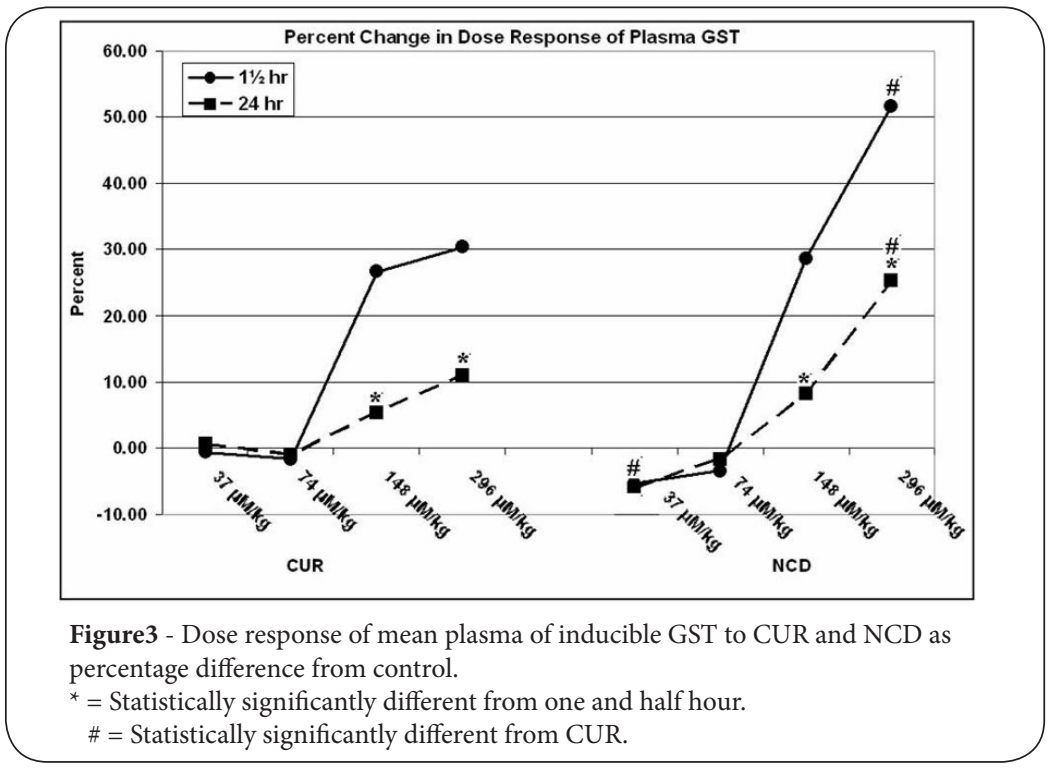

relative to the normal control levels together with statistical significance of differences in dose response characteristics of CUR and NCD on inducible plasma GST with respect to time and to each other.

The results point out to an almost identical curvilinear dose response curves of mean plasma inducible GST to the serial doubling concentrations of CUR and the NCD. A slight gradual decrease ranging from -0.059 to $-1.04 \%$ was found with the lower CUR doses of $37,74 \mu \mathrm{M} / \mathrm{Kg}$ body weight $\mathrm{mg} / \mathrm{kg}$ body weight for the $1.5 \mathrm{hr}$ and the 24 hour's duration studies, with one exceptional increase of $0.59 \%$ with the starting dose of CUR after 24 hours.

On the other hand, the extended 24 hour study points out to statistically non-significant differences lower CUR doses of 37, 74 $\mu \mathrm{M} / \mathrm{Kg}$ body weight, with highly statistically lower values for the higher doses, $(p<0.001)$.

Almost the same applies for the NCD, but with a higher range of decrease in the values of inducible plasma GST of -1.64 to -6.08 $\%$, pointing to higher potency, with $p$-values of $p<0.05$ to $p<0.001$ in favor of the NCD. Nevertheless, increasing the oral dose of both CUR and NCD to 148 and $296 \mu \mathrm{M} / \mathrm{Kg}$ body weight has changed the whole picture completely to elevations in the range of 5.28 to $30.14 \%$ for CUR and 8.11 to $51.70 \%$ for the NCD for the 1.5 and the 24 hours' durations studies, ending in statistically highly significant percent elevations in inducible plasma GST with $p$-value of $p<0.005$ to $p<0.001$ in favor of the NCD over CUR. However, the extended 24 hour study points out to statistically non-significant differences lower NCD doses of $37,74 \mu \mathrm{M} / \mathrm{kg}$ body weight, with highly statistically lower values for the higher doses, $(p<0.001)$. The inducible response of curcumin biomarker GST is more sharp and last longer in case of the NCD in comparison to CUR.

GST Dose response curves: Table 4 shows the nonlinear distance weighted least square fit of dose response lines of mean plasma inducible GST percentage of change from control to each of CUR and NCD. The dose dependent relationship is clear from the table.
There are statistically highly significant correlations of the equimolar increasing doses of each of CUR and NCD with the percentage change of inducible plasma GST. However, the correlation coefficient (r) is higher for the NCD than CUR for the $1.5 \mathrm{hr}$ and the $24 \mathrm{hr}$ studies. Curcumin showed $(r)$ values of 0.75 and 0.55 , while the NCD showed 0.92 and 0.81 for the respective studies.

From another point of view, the slopes of the correlation lines are more important for evaluating the dose-response relationship in the form of "impact", as the slope (b) represents the change in y, (the percentage change in inducible plasma GST) per unit change of $x$, (the micro molar concentration of each of the NCD and CUR). In this respect; Table 4 shows clearly higher slopes for the NCD as compared to CUR of 0.23 and 0.12 to 0.13 and 0.05 percent increase in inducible plasma GST for both the 1.5 and the $24 \mathrm{hr}$ studies, pointing again to more sharp and extended effect in case of the NCD in comparison to CUR.

\section{Discussion}

While cancer initiation and development implicates often hundreds of genes and/or signaling cascades, most conventional chemotherapeutic agents were designed to hit a single intracellular target and lead to severe adverse side effects, together with lack of safety. Efforts are directed to the development of multi-targeting therapies from safe and inexpensive, natural phytochemicals, despite difficulties to secure intellectual property rights to plant-based products.

In this respect, curcumin (diferuloylmethane), a natural hydrophobic polyphenol from the rhizomes of Curcuma longa, either native or formulated has shown significant promises against cancer [1] with ability to affect multiple intracellular targets [2] and inhibit specific molecular signaling pathways involved in carcinogenesis [3-5]. While reported to be antiproliferative in a number of cells lines $[4,5,7]$, it has low systemic bioavailability due to poor absorption, rapid metabolism and systemic elimination $[12,13]$. With its toxicity significantly higher in tumor cells than in normal cells [8], curcumin 
Abdel Aziz et al. Journal of Cancer Therapeutics \& Research 2012,

http://www.hoajonline.com/journals/pdf/2049-7962-1-10.pdf

doi: $10.7243 / 2049-7962-1-10$

could be considered as an ideal lead compound for anticancer drug development, with high dose safety up to $12 \mathrm{~g}$ /day [9-11].

To overcome these limitations, several covalent modifications of the curcumin molecule were tried. For example, multiple myeloma remains hardly curable malignancy, but with newly synthesized curcumin analogs, a 7-12 fold more potent growth suppressors of myeloma cells could be achieved [14].

The present work demonstrated that the anticancer effect of the "NCD" is retained and significantly improved in terms of lower micro molar IC50 against one normal and six human cancer cell lines in comparison to natural curumin. The results agree with countless number of published studies; only few will be referred to here.

Adams et al., 2004 [21], synthesized a series of curcumin analogs with higher degrees of anticancer potency than the chemotherapeutic drug, cisplatin. Following, Ohori et al., 2006 [22] pointed to a modified curcumin derivative with growth-suppressive activity 30 times that of natural curcumin. Expression of cancer-related genes usually affected by curcumin indicated that the derivative induced the down-regulation of $\beta$-catenin, Ki-ras, cyclin D1, c-Myc, and ErbB-2 at one eighth the concentration of curcumin. Much recently, Lin et al., 2010 [23] designed a novel molecule from curcumin to inhibit constitutive STAT3 signaling and demonstrated that it is an effective inhibitor of STAT3 phophorylation, DNA binding activity, downstream target gene expression and induces apoptosis in human multiple myeloma, glioblastoma, colorectal and liver cancers.

The present data demonstrate the conserved and improved in vivo structure-action relationships with the dose dependent induction of plasma GST. Park et al., 2010 [24] reported that curcumin induces GST expression by signaling through the nuclear erythroid-derived 2-related factor 2 (NRF-2) and NF-KB via an anti-oxidant response element. However, increased expression of GST isoenzymes is linked to the development of resistance to alkylating cytostatic drugs and their deficiency reportedly increased predisposition to various forms of cancer. Hence, GST status may be a useful prognostic factor to determine the clinical outcome of chemotherapy [16]. The present results agree with the published observation that GST enzyme activity has been shown to be up or down-regulated in rat tissues after oral consumption of curcumin, depending on the dose and route of administration [16]. In three patients on $36 \mathrm{mg}$ of curcumin daily, lymphocytic activity of GST was decreased with time to reach $41 \%$ of control on day 29 of treatment. This decline was not observed at the higher dose levels [16]. The effects of curcumin on GST expression are complex and may involve competitive enzyme inhibition as well as indirect enzyme induction [25]. Genetic polymorphisms in GST and its altered expression and activity are associated with oxidative DNA damage with subsequent risk of cancer susceptibility [26]. The inducible response of curcumin action biomarker GST is sharper and lasted longer in case of the NCD in comparison to CUR.

The nonlinear distance weighted least square fit of the dose response lines of mean plasma inducible GST percentage of change from control to each of CUR and NCD showed statistically highly significant correlations of the equimolar increasing doses of each of CUR and NCD with the percentage change of inducible plasma
GST. However, the correlation coefficient ( $r$ ) is higher for the NCD than CUR for the $1.5 \mathrm{hr}$ and the $24 \mathrm{hr}$ studies.

From another point of view, the slopes of the correlation lines are more important for evaluating the dose-response relationship in the form of "impact", as the slope (b) represents the change in y, (the percentage change in inducible plasma GST) per unit change of $(x)$, of micromolar concentration of each of the NCD and CUR.

In this respect higher slopes for the NCD as compared to CUR for both the $1.5 \mathrm{hr}$ and the $24 \mathrm{hr}$ studies were observed, pointing again to more sharp and extended effect in case of the NCD in comparison to CUR. However, with GST considered a biomarker for both CUR and cancer at the same time, it should not be used for either of them in studies or clinical trial of cancer treatment with CUR or its derivatives. Most recent studies have shown that the structure-action relationships of the symmetric curcumin molecule [1,7-bis(4-hydroxy3-methoxyphenyl)-1,6-heptadiene-3,5-dione] are strictly related to its phenolic hydroxyl and methoxy groups and the conjugated enones of the heptadiene moiety. As concerns the anticancer and GST induction potencies, Labbozzetta et al., 2009 [27] elaborated the diketone system of curcumin into different analogues; which showed remarkable increases in the antitumor potency both in the parental MCF-7 breast cancer cell line and in the amultidrug-resistant MCF-7R variant. They implied that the diketone fragment of curcumin is not indispensable for the growth inhibition and pro-apoptotic activities. The ability of curcumin analogues to induce phase II detoxification enzymes e.g. GST may be linked to the presence of both the phenolic hydroxyl groups and the diketone functionality of curcumin [28] and the conjugated enones act as Michael acceptors for curcumin's anti-cancer activity [29].

In general, oxyaryl substituent with an adjacent, unsaturated $\mathrm{C}=\mathrm{C}-\mathrm{C}=\mathrm{O}$ unit seems to offer antitumor and cancer cell cytotoxicity [30]. Meanwhile, its anti-inflammatory and anticancer activity, depends on low hydrogenation and a high level of methoxylation [31,32]. Other results indicates that the substitution of a hydroxyl group for a methoxy group at the meta positions of the phenyl rings in curcumin significantly enhanced the anti-inflammatory activity, and the removal of phenyl ring at the 7 th position of the heptadiene back bone and addition of hydroxyl group significantly increased the anti-proliferative activity of curcumin [33].

At this point, it is important to confirm that the core difference in curcumin derivatization was the site of modification and the type of the substituted chemical group, which was in all cases made through reactions with the naturally occurring functional chemical groups of the curcumin molecule. Here comes the difference, as the present NCD was made through covalent modification to remote sites, apart from such groups.

Assumptions of both conserving and improving the natural potencies of curcumin as anti cancer and in vivo GST dose dependent inducer was verified true. With GST as biomarker for both CUR and cancer, it should not be taken as a parameter in studies and/or clinical trial involving both cancer and CUR or its derivatives as GST is dose-dependently inducible by CUR and some of its derivatives. The present study opens the door wide for further in vivo structure- 
action relationship studies about the tremendous activities/potencies of the curcumin molecule in its novel covalently modified, conserved functional group form.

\section{Conflict of interests}

The authors declare that they have no competing interests.

Authors' contributions

Mohamed T.Abdel Aziz, Mohamed F.El-Asmar, Ameen M.Rezq participated in the design of the study and revised it critically; Hanan H.Fouad, Hanan H.Ahmed, Amira A. Hassouna, Fatma M.Taha carried out the performance of the animal experiments and the laboratory estimation of GST ; Hafez F.Hafez carried out the cell line study; Ameen M. Rezq performed the mathematical and statistical analysis and interpretation of data and drafted the manuscript. All authors read and approved the final manuscript.

\section{Author information}

${ }^{2}$ Medical Biochemistry Department, Faculty of

Medicine, Ain Shams University, Egypt.

${ }^{3}$ National Cancer Institute, Cairo University.

\section{Article history}

SE: Jiaoti Huang, David Geffen School of Medicine at UCLA, USA.

EIC: G.J. Peters, VU University Medical Center, Netherlands.

Received: 16-Apr-2012 Revised: 25-Apr-2012

Accepted: 03-May-2012 Published: 26-May-2012

\section{References}

1. Anand P, Sundaram C, Jhurani S, Kunnumakkara AB, Aggarwal BB: Curcumin and cancer: an "old-age" disease with an "age-old" solution. Cancer Lett 2008; 267;(1.);133-64. | Article | PubMed

2. Zaidi D, Singh N, Ahmad IZ, Sharma R, Balapure AK: Antiproliferative Effects of Curcumin Plus Centchroman In MCF7And MDA MB-231 Cells. Int J Pharm Pharm Sci 2011; 3(2):212-216. | Article

3. National Cancer Registry Programme, Time Trends in Cancer Incidence Rates 1982-2005, Indian Council of Medical Research Bulletin. 2009.

4. Senft C, Polacin M, Priester M, Seifert V, Kogel D, Weissenberger J: The nontoxic natural compound Curcumin exerts anti-proliferative, anti-migratory, and anti-invasive properties against malignant gliomas. BMC Cancer 2010; 10;(491). | Article | PubMed Abstract | PubMed Full text

5. Siwak DR, Shishodia S, Aggarwal BB, Kurzrock R: Curcumin-induced antiproliferative and proapoptotic effects in melanoma cells are associated with suppression of IkappaB kinase and nuclear factor kappaB activity and are independent of the B-Raf/mitogen-activated/extracellular signal-regulated protein kinase pathway and the Akt pathway. Cancer 2005; 104; (4.);879-90. | Article | PubMed

6. Aggarwal BB, Bhatt ID, Ichikawa H, Ahn KS, Sethi G, Sandur SK, Sundaram C, Seeram N, Shishodia S (2007) Curcumin-biological and medicinal properties, in: P.N. Ravindran, K.N. Babu, K. Sivaraman (Eds.), Turmeric the Genus Curcuma, CRC Press, NY, pp. 297-368.

7. Shao ZM, Shen ZZ, Liu CH, Sartippour MR, Go VL, Heber D, et al.: Curcumin exerts multiple suppressive effects on human breast carcinoma cells. Int J Cancer 2002; 98;(2.);234-40. | Article | PubMed

8. Kunwar A, Barik A, Mishra B, Rathinasamy K, Pandey R, Priyadarsini KI: Quantitative cellular uptake, localization and cytotoxicity of curcumin in normal and tumor cells. Biochim Biophys Acta 2008; 1780;(4.);673-9. | Article | PubMed

9. Sharma RA, McLelland HR, Hill KA, Ireson CR, Euden SA, Manson MM, et al.: Pharmacodynamic and pharmacokinetic study of oral Curcuma extract in patients with colorectal cancer. Clin Cancer Res 2001; 7;(7.);1894-900. | Article | PubMed

10. Chainani-Wu N: Safety and anti-inflammatory activity of curcumin: a component of tumeric (Curcuma longa). I Altern Complement Med 2003; 9;(1.);161-8. | Article | Pubmed Abstract | PubMed

11. Lao CD, Ruffin MTt, Normolle D, Heath DD, Murray SI, Bailey JM, et al.: Dose escalation of a curcuminoid formulation. BMC Complement Altern
Med 2006; 6;(10). | Article | PubMed Abstract | PubMed Full text

12. Anand $P$, Kunnumakkara $A B$, Newman RA, Aggarwal BB: Bioavailability of curcumin: problems and promises. Mol Pharm 2007; 4;(6.);807-18. | Article | PubMed

13. Burgos-Moron E, Calderon-Montano JM, Salvador J, Robles A, Lopez-Lazaro M: The dark side of curcumin. Int J Cancer 2010; 126;(7.);1771-5. I Article I PubMed

14. Kudo C, Yamakoshi H, Sato A, Ohori H, Ishioka C, Iwabuchi Y, et al.: Novel curcumin analogs, GO-Y030 and GO-Y078, are multi-targeted agents with enhanced abilities for multiple myeloma. Anticancer Res 2011; 31;(11.);3719-26. | Article | PubMed

15. Sharma RA, Euden SA, Platton SL, Cooke DN, Shafayat A, Hewitt HR, et al.: Phase I clinical trial of oral curcumin: biomarkers of systemic activity and compliance. Clin Cancer Res 2004; 10;(20.);6847-54. | Article | PubMed

16. Wu Z, Minhas GS, Wen D, Jiang H, Chen K, Zimniak P, et al.: Design, synthesis, and structure-activity relationships of haloenol lactones: site-directed and isozyme-selective glutathione S-transferase inhibitors. J Med Chem 2004; 47;(12.);3282-94. | Article I PubMed

17. Rezq A, Abdel Aziz MT, and Kumosani TA.PCT/EG2008/000044, Published Patent Pending, WO 2010/057503, Regional phase European Patent Application No. 08878223.

18. Stoddart MJ: Cell viability assays: introduction. Methods Mol Biol 2011; 740. | Article | PubMed

19. Skehan P, Storeng R, Scudiero D, Monks A, McMahon J, Vistica D, et al.: New colorimetric cytotoxicity assay for anticancer-drug screening. J Nat/ Cancer Inst 1990; 82;(13.);1107-12. | Article | PubMed

20. Habig WH, Pabst MJ, Jakoby WB: Glutathione S-transferases. The first enzymatic step in mercapturic acid formation. J Biol Chem 1974; 249;(22.);71309. | Article | PubMed

21. Adams BK, Ferstl EM, Davis MC, Herold M, Kurtkaya S, Camalier RF, et al.: Synthesis and biological evaluation of novel curcumin analogs as anti-cancer and anti-angiogenesis agents. Bioorg Med Chem 2004; 12;(14.);387183. | Article | PubMed

22. Ohori H, Yamakoshi H, Tomizawa M, Shibuya M, Kakudo Y, Takahashi A, et al.: Synthesis and biological analysis of new curcumin analogues bearing an enhanced potential for the medicinal treatment of cancer. Mol Cancer Ther 2006; 5;(10.);2563-71. I PubMed

23. Lin L, Deangelis S, Foust E, Fuchs J, Li C, Li PK, et al.: A novel small molecule inhibits STAT3 phosphorylation and DNA binding activity and exhibits potent growth suppressive activity in human cancer cells. Mol Cancer 2010; 9;(217). | Article | PubMed Abstract | PubMed Full text

24. Park J, Conteas CN: Anti-carcinogenic properties of curcumin on colorectal cancer. World J Gastrointest Oncol 2010; 2;(4.);169-76. | Article | PubMed Abstract | PubMed Full text

25. Sharma RA, Ireson CR, Verschoyle RD, Hill KA, Williams ML, Leuratti C, et al.: Effects of dietary curcumin on glutathione S-transferase and malondialdehyde-DNA adducts in rat liver and colon mucosa: relationship with drug levels. Clin Cancer Res 2001; 7;(5.);1452-8. | Article | PubMed

26. Khan MA, Tania M, Zhang D, Chen H: "Antioxidant enzymes and cancer". Chin J Cancer Res 2010; 22(2):87-92. | Article

27. Labbozzetta M, Notarbartolo M, Poma P, Maurici A, Inguglia L, Marchetti $P$, et al.: Curcumin as a possible lead compound against hormone-independent, multidrug-resistant breast cancer. Ann N Y Acad Sci 2009; 1155;(27883). | Article | PubMed

28. Dinkova-Kostova AT, Talalay P: Relation of structure of curcumin analogs to their potencies as inducers of Phase 2 detoxification enzymes. Carcinogenesis 1999; 20;(5.);911-4. I Article | PubMed

29. Rajasekaran SA: Therapeutic potential of curcumin in gastrointestinal diseases. World J Gastrointest Pathophysiol 2011; 2;(1.);1-14. | Article | PubMed Abstract | PubMed Full text

30. Anand $P$, Thomas SG, Kunnumakkara AB, Sundaram C, Harikumar KB, Sung B, et al.: Biological activities of curcumin and its analogues (Congeners) made by man and Mother Nature. Biochem Pharmacol 2008; 76;(11.);1590-611. | Article | PubMed

31. Kelkel M, Jacob C, Dicato M, Diederich M: Potential of the dietary antioxi- 
Abdel Aziz et al. Journal of Cancer Therapeutics \& Research 2012,

http://www.hoajonline.com/journals/pdf/2049-7962-1-10.pdf

doi: $10.7243 / 2049-7962-1-10$

dants resveratrol and curcumin in prevention and treatment of hematologic malignancies. Molecules 2010; 15;(10.);7035-74. | PubMed

32. Singh U, Barik A, Singh BG, Priyadarsini KI: Reactions of reactive oxygen species (ROS) with curcumin analogues: Structure-activity relationship. Free Radic Res 2011; 45;(3.);317-25. | Article I PubMed

33. Ravindran J, Subbaraju GV, Ramani MV, Sung B, Aggarwal BB: Bisdemethylcurcumin and structurally related hispolon analogues of curcumin exhibit enhanced prooxidant, anti-proliferative and anti-inflammatory activities in vitro. Biochem Pharmacol 2010; 79;(11.);1658-66. | Article | PubMed Abstract | PubMed Full text

\section{Citation:}

Abdel Aziz MT, El-Asmar MF, Rezq AM, Fouad $\mathrm{HH}$, Ahmed HH, Hassouna AA, Taha FM and Hafez HF: Novel Anticancer Curcumin Derivative with Conserved Functional Groups. journal of Cancer Therapeutics and Research 2012, 1:10.

http://dx.doi.org/10.7243/2049-7962-1-10 